Veröffentlichungen der Abteilung Sozialstruktur und Sozialberichterstattung des Forschungsschwerpunktes Sozialer Wandel, Institutionen und Vermittlungsprozesse des Wissenschaftszentrums Berlin für Sozialforschung

FS III $00-402$

\title{
Modernity and Happiness The Case of Germany
}

\author{
Thomas Bulmahn
}

März 2000

Abteilung „Sozialstruktur und Sozialberichterstattung" im Forschungsschwerpunkt III

Wissenschaftszentrum Berlin für Sozialforschung (WZB)

Reichpietschufer 50, D - 10785 Berlin

Telefon 030 - 25491 - 0 



\section{Abstract}

The question asked in this paper is whether modern societies enable the individual to lead a happier life. It was hoped during the Age of the Enlightenment that rationally designed social conditions would lead in the future to greater prosperity, more security and increased happiness for all. Only a little of this optimism has survived into the twentieth century. In their studies on anomie, sociologists such as Durkheim, Merton and Sennett have drawn attention to the darker sides of progress. Current theories of anomie - explicit social critiques - entirely ignore the successes of modernity and discuss only its crises. In these theories, anomie is described as a structural feature of modern societies, whose destructive consequences are manifested by growing alienation, increasing social isolation and rising suicidality. Empirical analyses of data from Germany show, however, that these theses diverge from the reality. Despite rapid processes of modernisation, anomic patterns of perception and behaviour have not become more widespread over the last 20 years; on the contrary, in some areas anomie has decreased significantly. Proceeding from this insight, this article proposes a correction of those models of anomie that are blind to progress. The crises of modernity are confronted with its successes, which have helped considerably to reduce anomic reactions and to stabilise subjective well-being at a high level. Finally, the article points out that this is not a stable equilibrium, rather that temporal and structural imbalances may occur in the course of modernisation processes, whose magnitudes may, however, be curbed - albeit not entirely or in every respect. 



\section{Contents}

I The dark side of progress: anomie in modern society 3

II Catch-up modernisation in Germany 6

III Subjective well-being and anomic tendencies in Germany 10

$\begin{array}{ll}\text { IV The ambivalence of modernity } & 18\end{array}$

$\begin{array}{lll}\text { V Temporal and structural imbalances } & 21\end{array}$

$\begin{array}{ll}\text { Summary } & 22\end{array}$

$\begin{array}{ll}\text { Literature } & 24\end{array}$ 



\title{
I The dark side of progress: anomie in modern society
}

\author{
"But, in fact, is it true that the happiness of the individual \\ increases as man advances? Nothing is more doubtful." \\ Émile Durkheim (1960 [1893], p. 241)
}

The ambivalence of progress is one of the central topics of modernity. Writers, composers, painters and philosophers have repeatedly addressed the question as to whether modern society enables the individual to lead a happier life. Doubts had arisen as early as the mid-eighteenth century with respect to this mechanistic view of the world and to the belief in progress characteristic of the Enlightenment. In 1754 Jean-Jacques Rousseau had published the first comprehensive critique of modern society, entitled $D e$ l'inégalité parmi les hommes. Rousseau argued that individuals are forced by civilisation to live contrary to their nature; they are robbed of their freedom and become increasingly socially dependent; they lose their cognitive capacity and their true character is ruined. He claimed that "in the midst of so much philosophy, humanity and civilisation, and of such sublime codes of morality" life in modern society is nothing but "a frivolous and deceitful appearance, honour without virtue, reason without wisdom, and pleasure without happiness." (Rousseau 1913 [1754] pp. 207-238).

Within sociology it was Émile Durkheim who provided the first important reflections on the ambivalence of social progress. Durkheim's view was that the increasing division of labour had significant implications for social cohesion (Durkheim 1960 [1893]). On the one hand, he claimed, functional differentiation leads to increasing social differentiation. As a result, mechanical solidarity, that based on social similarity, weakens (ibid. pp. 70-110). On the other hand, the division of labour engenders a new form of social cohesion, an organic solidarity that is based on the heterogeneity of individuals (ibid. pp. 111-132). "In effect [...] each one depends as much more strictly on society as labor is more divided; and [...] the activity of each is as much more personal" (ibid. p. 131).

Durkheim saw no guarantee that the change from mechanical to organic solidarity would prove successful. In fact he was afraid that the dynamic of economic development, the struggle between capital and labour, and the increasing disunity of the sciences would lead to an abnormal form of the division of labour that did not generate new solidarity (ibid. pp. 353-409). Durkheim traced the threat to social cohesion back to social crises that weaken the ties between the individual and society, and he termed this 
state of rulelessness "anomie". The consequences of this breakdown in social integration, claimed Durkheim in his treatise Suicide - A Study in Sociology, are rootlessness, social isolation, and a rising propensity to commit suicide (Durkheim 1963 [1897]).

Around the turn of the century there was widespread awareness of the darker sides of modernisation. For Max Weber, ongoing rationalisation was tantamount, on the one hand, to social progress. The acme of rationalisation was perceived by Weber in bureaucratic organisation, a form of organisation superior to any other: "No machinery in the world functions so precisely as this apparatus of men and, moreover, so cheaply ..." (Weber 1968 [1921], p. 223). On the other hand, Weber warned against total subjugation under instrumental rationality. In a completely bureaucratised society, individuals would find themselves imprisoned by rationality. "The great question is [...] what can we oppose to this machinery in order to keep a portion of mankind free from this parceling-out of the soul, from this supreme mastery of the bureaucratic way of life" (Weber 1958 [1946], p. 212).

Contemporaries of Weber expressed similar misgivings. Ferdinand Tönnies was concerned that tradition, faith and the sense of community were being displaced by increasing commercialisation and the spread of scientific methods (Tönnies 1991 [1887]). Georg Simmel pointed to the social and psychological problems associated, in his view, with the introduction of the modern monetary economy (Simmel 1994 [1900]).

In the mid-1960s the American sociologist Robert K. Merton propounded his conception of anomie, which differed in a number of important respects from Durkheim's approach. Merton proceeded from a distinction between cultural structure and social structure (Merton 1968). It is in the cultural structure of a society, he argued, that the generally accepted views of the meaning of human life are anchored (ibid. pp. 186-193). Merton considered success and wealth to be among the predominant individual goals of American society - the American way of life. Yet alongside these "cultural goals", the cultural structure also contains the paths - termed "institutional norms" - by which these goals can be attained. The social structure, by contrast, describes the actually existing ways of legally attaining the predetermined goals.

If there is little access to conventional and legitimate means for becoming successful, deviant forms of behaviour become increasingly common. This undermining of the extant norms ultimately leads to the collapse of the cultural structure, that is, to anomie (ibid. p. 198f.). Because of the absence of realistic opportunities for advancement in the 
lower strata of society, deviant behaviour is particularly common amongst this class, as evidenced by statistics on criminality (ibid. p. 198).

The differences between Durkheim's concept of anomie and Merton's approach are readily evident: whereas Durkheim based his approach on the threat of rulelessness resulting from a lack of social cohesion, Merton emphasises the inequality of the opportunities to attain legitimate goals by legal means. According to Durkheim, the societies most at risk of anomie are those in which the pace of differentiation exceeds that of social integration; for Merton the social groups most endangered by anomie are those that simply lack the adequate means to attain the aims set for them by society.

In recent years a more subject-centred conception of anomie has once again been propounded. Rousseau's view that modern society deforms individuals, makes them unfree, dependent and unhappy has enjoyed a renaissance at the threshold to the twenty-first century. With his study The Corrosion of Character, which deals with the psycho-social consequences of the new, global capitalism, Richard Sennett has published one of the best-researched analyses in this area (Sennett 1998).

According to Sennett, this new economic system is geared wholly towards flexibility and the short run, in accordance with the motto "No long term". Sennett offers a large number of empirical observations in support of his hypothesis that time has been restructured. He points to the cult of re-engineering, to the increasing number of permanent jobs converted into fixed-term projects and flexible work areas, and to the expanding market for temporary employment (ibid. pp. 46-63).

What Sennett considers more important than describing the culture of the new capitalism, however, are the consequences for individuals of the increasingly short-term orientation of working life. He asks (ibid. p. 26): How can individuals continue to pursue long-term aims? How can they develop lasting social relationships? How can identities be created? Are reliability, single-mindedness and loyalty still characteristics that are required by today's world? Human needs for continuity, security, meaning, identity and social integration are increasingly difficult to reconcile with the flexibility of the new capitalism. "The conditions of time in the new capitalism have created a conflict between character and experience" (ibid. p. 31). Sennett believes that enforced flexibility and mobility, that is, the drift from one job to the next and from one place to another, leads to alienation, feelings of meaninglessness and social isolation. 
In very different ways, Durkheim, Merton and Sennett have drawn attention in their studies to the negative sides of progress: Durkheim to the creeping dissolution of society and the rulelessness associated with this process; Merton to the discrepancy between cultural goals and the legal means to attain them, which leads to deviant behaviour; and Sennett to the erosion of human character in a global capitalism based on flexibility. What unites these authors, however, are their misgivings that modernisation processes make people more lonely, insecure and unhappy.

\section{Catch-up modernisation in Germany}

"We Germans do not have ourselves to thank for the fact that, at the end of this century, we are after all united in the world of civil rights, institutionalised conflicts, guaranteed freedom and legal security."

M. Rainer Lepsius (1995, p. 30)

German history during the last fifty years is a history of catch-up modernisation (nachholende Modernisierung), and both the direction and the dynamic of social development have been determined to a considerable degree by exogenous impulses.

In western Germany, it was under the auspices of the western occupying powers that the first steps were taken towards establishing the social market economy and representative democracy. On the basis of these institutions and the support provided under the USA's European Recovery Program (Marshall Plan), developments occurred that were successful in both economic and political terms (Benz 1989). In retrospect the 1950s and 1960s appear as a golden age: incomes and living standards rose substantially, while at the same time working time was reduced and working conditions improved. The welfare state was extended, improving protection against the financial implications of unemployment, sickness, disability and old age. Freedom, wealth and security were experienced by virtually all strata of the population - albeit to varying extents. Yet it would be to distort reality to claim that these changes occurred without conflict: wage increases and cuts in working hours, for instance, were only achieved against bitter opposition. 
At the end of the 1960s the intensity of social conflict increased substantially, sparked off by international protests against the Vietnam War. The student-led anti-authoritarian protest movement initially demanded democratic reforms in the universities, and later radical changes in social structures. Although the New Left failed in its aim to abolish all existing structures of power and authority, the student protests changed the face of society, accelerating the processes of democratisation and liberalisation, which had become bogged down in the preceding years.

In the mid-1970s exogenous shocks once again led to social upheavals. The oil-price shock led to a serious recession, in the course of which unemployment rose sharply. Just a few years later a second severe economic crisis led to a further rise in unemployment. The social security systems that had been expanded in times of full employment had to be stabilised with the help of government grants, which in turn led to a doubling of government debt as a proportion of GDP, from 20 to 40 percent within a decade. At the same time, the environmental damage produced by the unabated economic growth became increasingly evident.

The question of how to interpret the political, economic and social turbulence of the 1970s and 1980s remains a controversial one (see the contributions to Berger 1986). Proponents of theories focusing on innovation and modernisation, such as Walter L. Bühl and Wolfgang Zapf, have interpreted them as problems of a transition from one "Kondratieff cycle" to the next (Bühl 1986; Zapf 1986). In order to accelerate this process they recommended innovation-promoting measures, encompassing a broad spectrum of deregulation and active innovation policies (Zapf 1986, p. 173). These authors considered further-reaching economic and social reforms to be superfluous. "Competitive democracy, a market economy and a prosperous society with a welfare state and mass consumption are the fundamental institutions within which struggles for innovation take place" (Zapf 1991, p. 46). The future of western industrialised societies was interpreted as a process of "ongoing modernisation", ongoing "in the double sense of consistency of direction and structural improvement" (ibid.).

Yet, as Zapf himself concedes, there are arguments against the hypothesis of ongoing modernisation that deserve serious consideration: evidence of the social limitations on growth; concerns that increasing individualisation and the loss of steering capacity might erode modern institutions; signs that institutional change is proceeding so dramatically that an epoch-making break is imminent; and, finally, doubts as to whether the programme of ongoing modernisation can cope with the global risks and dangers en- 
tailed (ibid. p. 47). These problems are recognised as challenges that modern societies, such as Germany, must face. They are not accepted, however, as objections to the thesis of ongoing modernisation, because, states Zapf, there are currently "no more effective alternatives", institutions that can better solve the problems we face than the market economy, democracy and the welfare state (ibid.).

Proponents of a theory of "reflexive modernisation", such as Ulrich Beck, Anthony Giddens and Scott Lash (1996), on the other hand, interpret the prevailing economic, social and ecological problems as symptoms of a systemic crisis. They argue that modern industrial societies, by virtue of their very success, have undermined their own natural and social foundations. They derive from this interpretation the necessity of a "reflexive modernisation", the "application of modernisation to itself" (Beck \& Bonß 1984, p. 385). What is required is a "reflexive modernity" which, according to Beck, is both a "project and a product of modernity" and at the same time is an alternative to it in the sense of a "counter-modernity" (Beck 1996, p. 59). Yet this "project of a countermodernity" has remained very vague to date. Concrete ideas on the institutional design of a reflexive modernity have yet to be developed.

In eastern Germany the path taken by social development was less successful. Immediately after the end of the war, the Soviet military administration initiated a process that was to restructure the economy and society on socialist lines (Weber 1999). Following the Soviet example, a centrally planned economy and a one-party system were established, which subsequently provided the institutional basis for this anti-capitalist modernity (Brie 1992). Although significant progress was made in industrialising the country in the early years, this did not lead to the fundamental improvement in living conditions desired by the population. Comparison with the more successful western half of the country led to dissatisfaction, and between 1949 and 1961 around three million people left the country, more or less voluntarily.

Following the erection of the Berlin Wall in 1961 the socialist regime consolidated its position relatively successfully. However, ongoing attempts to reform the highly centralised economic system had to be suspended under instruction from the Soviet leadership, as did the cautious liberalisation of society. During the 1970s the party and state leadership undertook new efforts to stabilise their power: internally by pursuing a strategy of so-called "unity of economic and social policy"; externally by seeking to improve the relationship with West Germany. 
Initially both strategies appeared successful. In the 1980s, however, their effects proved destructive to an extent that was inconceivable previously. The costly social policy accelerated economic decline and brought the country to the brink of bankruptcy. Moreover, in its efforts to improve relations with the Federal Republic, the leadership of the German Democratic Republic (GDR) had signed the Helsinki Final Communiqué and thus committed itself to respecting human and civil rights. Thousands of GDR citizens subsequently used this commitment to justify their demands for the basic right to travel and to express their opinions freely. Popular optimism concerning liberalisation increased when wide-ranging reforms were implemented in the Soviet Union. The civil rights groups intensified their activities, and the number of people attempting to leave the country rose. At the end of the 1980s mass protest and mass exit attained a dynamic that finally led to the collapse of the communist regime (Hirschman 1992).

Jürgen Habermas was one of the first to interpret the upheaval throughout eastern Europe as a "catch-up revolution" (nachholende Revolution), that is, as a revolution that "frees the path to catch up on missed developments" (Habermas 1990, p. 180). This prophecy was to prove particularly apposite in the case of eastern Germany. In the first free parliamentary elections in the GDR, held in March 1990, a majority of the population voted for the "Alliance for Germany", and thus for a swift unification of the two German states. The coming into force of the Treaty on Economic, Monetary and Social Union and of the Unification Treaty marked the start of a process of "catch-up modernisation" in eastern Germany. The aim of this transition process was clearly defined: it was to "import, establish and incorporate modern democratic, market-economic and legal-constitutional institutions" (Zapf 1994, p. 301).

Because the West German set of institutions was assumed completely and unchanged as a "ready-made state" (Rose et al. 1993), transition occurred at a hugely accelerated pace. This "modernisation at time-lapse speed" (Geißler 1992) led to a series of economic distortions, incurring substantial social costs. Within months unemployment rose from just a few thousand to over one million; by 1993 more than a third of all jobs had been lost; the birth rate fell dramatically; and once again thousands of eastern Germans left the country. 


\section{Subjective well-being and anomic tendencies in Germany}

"Since progress has become self-propelling, future optimism has turned into procedural melancholy."

Peter Sloterdijk (1988, p. 263)

In the late 1990s Bohle, Heitmeyer, Kühnel and Sander (Bohle et al. 1997) presented an ambitious concept for the analysis of anomic tendencies in modern societies like Germany. In the view of these authors, modernisation processes in individual parts of society take the form of "rapid, undirected, non-simultaneous and contradictory developments" (ibid., p. 59). These developments lead to "tensions" in different areas of society, which intensify and become crises. Bohle et al. distinguish between three types of crisis in modern society: the "structural crisis", the "regulation crisis" and the "cohesion crisis" (ibid.). Structural crises are characterised by breakdowns in social structure, in particular by growing social inequality, by the exclusion of segments of the population and by "poverty in conditions of prosperity" (Bohle et al. 1997, p. 59). Regulation crises, by contrast, are evidenced by "non-conformity of aspirations and factual circumstances" and "weakened effectiveness of norms" (ibid.). Cohesion crises are manifested by the "disintegration or weakening of bonds" (ibid.).

The authors' intention to unite Merton's (presented here as a structural or regulation crisis) and Durkheim's (cohesion crisis) concepts of anomie in their approach is already apparent at this point. This intention becomes even clearer when Bohle et al. establish a link between modernisation processes in parts of society and individuals' ways of processing them at the levels of attitude and action. Structural crises, they believe, lead to "innovation, ritualisation, withdrawal, protest and criminality" (ibid., p. 59) - behaviour patterns that largely correspond to Merton's typology (Merton 1964, p. 194). Regulation crises, claim the authors, cause "loss of orientation, loss of plausibility and uncertainty" (Bohle et al. 1997, p. 59). Cohesion crises, in concordance with Durkheim's view, are seen to lead to "alienation, identity problems, isolation and suicide" (ibid.).

Bohle et al. believe that the crises of modernity do not have a direct effect on individual behaviour, rather that strengthening or weakening occur at the intermediary level. On this view, symptoms of anomie do not, therefore, spread simultaneously through all spheres of society, nor do they manifest themselves only in one way (ibid., p. 62). Nevertheless, Heitmeyer sees much evidence for the view that anomie is "not a transitory 
phenomenon that recurs episodically", rather is a "structural feature of modern societies" (Heitmeyer 1997, p. 16). He believes that this applies in particular to Germany, because "reunification, the collapse of the political system in the East, the globalisation of capital and communication, mass unemployment, and cultural, religious and ethnic conflicts $[\ldots]$ have led to a profound uncertainty and helplessness, which permeates all areas of society and whose destructive consequences at both the individual and collective level have to date neither been adequately recognised nor discussed" (ibid., p. 10). Among the indicators that can expose these "destructive consequences", he lists feelings of meaninglessness and powerlessness, apathy and suicidal tendencies (ibid., p. 16). The cautious misgivings of Durkheim, Merton and Sennett that modernisation processes could make people more lonely, insecure and unhappy have given way in Heitmeyer to a questionable certainty.

The following discussion will seek to determine the extent of anomic tendencies in Germany on the basis of the above and a range of other indicators. At the heart of the discussion are four questions: Are dissatisfaction and anxiety really growing? Are the Germans truly becoming increasingly unhappy? To what extent is there an increase in the frequency of anomic reactions such as powerlessness, loneliness, meaninglessness, disorientation and pessimism? Has the propensity to commit suicide increased or decreased?

The analyses are based on data from the German Welfare Survey (Wohlfahrtssurvey) and from the official statistics of the Federal Republic of Germany. The Welfare Survey is a social science population survey of objective living conditions and subjective wellbeing (Glatzer \& Zapf 1984; Habich \& Noll 1999). The first Welfare Survey was carried out in West Germany in 1978. Additional polls followed in 1980, 1984 and 1988. The respondents had German citizenship and were at least 18 years of age. Data were first collected in eastern Germany in 1990. The first Welfare Survey of unified Germany took place in 1993, the second in 1998. During the latter survey, 2,007 persons were questioned in the former West Germany and 1,035 persons in the former GDR.

Life satisfaction, which is based on a range of comparisons and weightings, is considered to represent a broad assessment of personal living conditions. Current living conditions are compared with those desired, with those of the past and with those aspired to in the future for oneself or relevant reference persons. In addition to individual levels of aspiration, the significance given to different areas of life is also important. Thus, life 
satisfaction is the total of a cognitive sum of all factors. The Welfare Survey measures life satisfaction on a scale from 0 (completely dissatisfied) to 10 (completely satisfied).

Table 1: Life Satisfaction of German citizens in the West and in the East

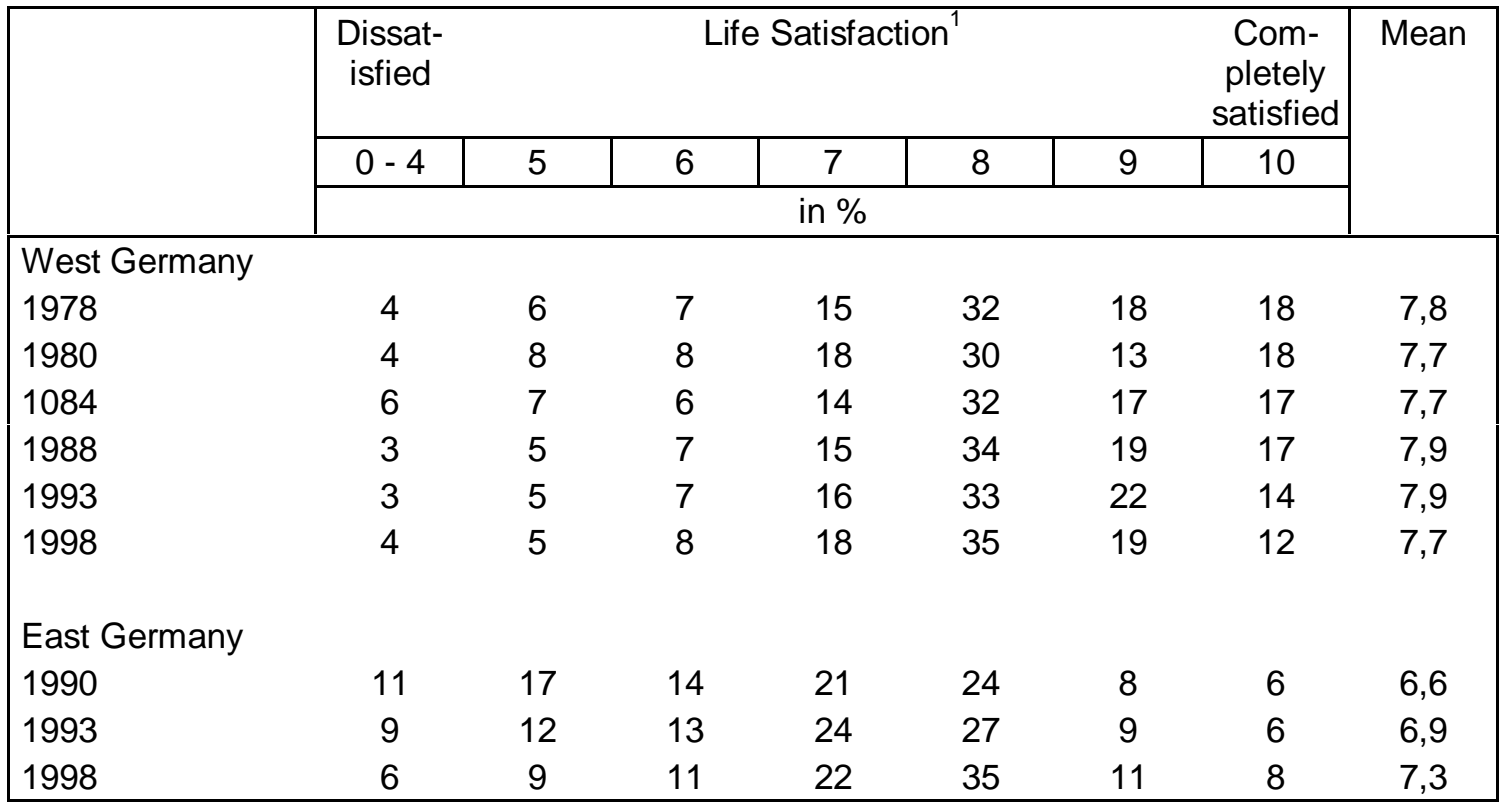

${ }^{1}$ Question: „What do you mean, how satisfied are you at present with your life in general?“ Measured on a scale from 0 (completely dissatisfied) to 10 (completely satisfied).

Database: Welfare Survey 1978, 1980, 1984, 1988, 1990-East, 1993, 1998.

The large majority of the population of western Germany ranked itself in the top half of the scale in 1998 (see Table 1). A large share of people are very satisfied with their own life, while around every tenth person is completely satisfied (Level 10). Only a small minority is dissatisfied (Levels 0-4). A comparison with the results from 1978 shows that satisfaction with life in western Germany has consolidated. The high levels of satisfaction recorded as early as the late 1970s have hardly varied since. The share of those who are completely satisfied with their lives (Level 10) has declined the most.

Conspicuous variations have occurred in the eastern German data in recent years. The distribution of satisfied respondents has become very similar to the pattern for western Germany, without yet being fully identical. The share of those who are satisfied with their lives has increased, mirrored by a decline in the share of those who are more dissatisfied. There are still differences at the highest levels: the share of those who are completely satisfied is still smaller than in the west. The mean for satisfaction has risen from 6.6 to 7.3, and the distance to the western level of satisfaction has fallen from 1.3 points to 0.4 points over the same period. 
The sense of happiness is another indicator used to describe subjective well-being. While life satisfaction is considered to be primarily an expression of cognitive wellbeing, happiness is more a indication of emotional welfare.

Table 2: Happiness of German citizens in the West and in the East

\begin{tabular}{|c|c|c|c|c|}
\hline & \multicolumn{4}{|c|}{$\begin{array}{c}\text { Taking all things together, how would you say things are these days } \\
\text { would you say you are... }\end{array}$} \\
\hline & Very unhappy & Not too happy & Pretty happy & Very happy \\
\hline & \multicolumn{4}{|c|}{ in $\%$} \\
\hline \multicolumn{5}{|c|}{ West Germany } \\
\hline 1978 & 1 & 4 & 74 & 22 \\
\hline 1980 & 1 & 5 & 69 & 26 \\
\hline 1984 & 1 & 8 & 72 & 20 \\
\hline 1988 & 1 & 4 & 72 & 23 \\
\hline 1993 & 1 & 5 & 70 & 24 \\
\hline 1998 & 1 & 8 & 72 & 20 \\
\hline \multicolumn{5}{|c|}{ East Germany } \\
\hline 1990 & 1 & 14 & 74 & 10 \\
\hline 1993 & 1 & 12 & 75 & 12 \\
\hline 1998 & 1 & 11 & 72 & 16 \\
\hline
\end{tabular}

Database: Welfare Survey 1978, 1980, 1984, 1988, 1990-East, 1993, 1998.

As in the case of life satisfaction, the sense of happiness amongst western Germans has also changed only insignificantly in recent years (see Table 2). The share of those who considered themselves to be very happy has amounted to between 20 and 26 percent in all the surveys carried out since 1978, and the majority of the western German population has responded that they are currently more happy than unhappy. Only a minority responded that they were currently leading an unhappy life.

In eastern Germany the population is now not only more satisfied with life, but also happier. In 1990, 10 percent of eastern Germans responded that their life was currently "very happy", and this share had risen to no less than 16 percent in 1998. The distance to the western German level for sense of happiness also decreased, and the distribution patterns have become more similar.

The findings presented so far portray a largely satisfied and happy population. International comparisons show that the level of subjective well-being found in Germany is not unusually high, rather that it represents the average (Veenhoven 1992; Cummins 1998; 
Diener \& Suh 1999). It appears that in most western societies "most people are happy" (Diener \& Diener 1996).

Table 3: Agreement of German citizens in the West and in the East to items of anxiety ${ }^{1}$

\begin{tabular}{|c|c|c|c|c|c|c|}
\hline & $\begin{array}{c}\text { Do you of- } \\
\text { ten get } \\
\text { spells of } \\
\text { exhaustion } \\
\text { or fatigue? }\end{array}$ & \begin{tabular}{|c|} 
Do fright- \\
ening \\
thoughts \\
again and \\
again come \\
back in your \\
mind? \\
\end{tabular} & $\begin{array}{c}\text { Are you } \\
\text { constantly } \\
\text { keyed up } \\
\text { and jittery? }\end{array}$ & $\begin{array}{c}\text { Do you usu- } \\
\text { ally feel } \\
\text { unhappy or } \\
\text { depressed? }\end{array}$ & $\begin{array}{l}\text { Do you of- } \\
\text { ten } \\
\text { shake or } \\
\text { tremble? }\end{array}$ & $\begin{array}{c}\text { None of the } \\
\text { symtoms of } \\
\text { anxiety }^{2}\end{array}$ \\
\hline & \multicolumn{6}{|c|}{ in \% } \\
\hline \multicolumn{7}{|c|}{ West Germany } \\
\hline 1978 & 54 & 19 & 16 & 14 & 9 & 41 \\
\hline 1984 & 47 & 21 & 16 & 15 & 8 & 44 \\
\hline 1988 & 44 & 19 & 12 & 10 & 6 & 47 \\
\hline 1993 & 39 & 17 & 10 & 10 & 6 & 53 \\
\hline 1998 & 39 & 20 & 9 & 12 & 4 & 54 \\
\hline \multicolumn{7}{|c|}{ East Germany } \\
\hline 1990 & 50 & 27 & 18 & 17 & 7 & 37 \\
\hline 1993 & 43 & 26 & 14 & 16 & 6 & 44 \\
\hline 1998 & 45 & 25 & 12 & 15 & 5 & 43 \\
\hline
\end{tabular}

1 Share of saying „Yes“ in percent.

2 Share of saying „No" to all five items of anxiety in percent.

Database: Welfare Survey 1978, 1980, 1984, 1988, 1990-East, 1993, 1998.

The analysis of symptoms of anxiety and anomie in general leads to the same conclusion, although it is apparent that people's lives are not entirely free of fears and worries. Around half of the German population complains of mental strain, and many - 39 percent of westerners and 45 percent of easterners - often feel exhausted (see Table 3). One fifth of the westerners and a quarter of the easterners have fears and worries.

Only a few respondents, however, report permanent difficulties: only every tenth person is constantly agitated and nervous or usually feels unhappy or despondent. The extent of mental strain has decreased steadily over the last 20 years. The number of western Germans reporting states of exhaustion, agitation or nervousness is in constant decline. In 1998, 54 percent of the respondents had none of the above symptoms, against only 41 percent in 1978. The situation has also improved considerably in eastern Germany, and the share of those who have no symptoms of anxiety has increased significantly. 
A multi-dimensional concept is used to measure anomic reactions in the narrower sense. The five dimensions were surveyed using the following indicators: powerlessness: agreement with the statement "I can do little to change most of our current problems"; social isolation: agreement with the statement "I often feel lonely"; alienation: agreement with the statement: "I don't really enjoy my job"; disorientation: agreement with the statement: "Life has become so complicated that I almost can't cope"; pessimism: disagreement with the statement "When I think about the future I'm really quite confident".

Table 4: Agreement of German citizens in the West and in the East to items of anomie

\begin{tabular}{|l|c|c|c|c|c|}
\hline & \multicolumn{5}{|c|}{ Dimensions of Anomie } \\
\cline { 2 - 6 } & $\begin{array}{c}\text { Power- } \\
\text { lessness }\end{array}$ & $\begin{array}{c}\text { Social } \\
\text { Isolation }\end{array}$ & Alienation & Disorientation & Pessimism \\
\cline { 2 - 6 } & \multicolumn{5}{|c|}{ in \% } \\
\hline West Germany & 69 & 17 & - & - & - \\
1978 & - & 18 & 15 & 15 & - \\
1980 & - & 17 & 15 & 14 & - \\
1984 & - & 14 & 14 & 11 & - \\
1988 & 74 & 13 & 11 & 13 & 43 \\
1993 & 67 & 16 & 12 & 14 & 33 \\
1998 & & & & & \\
& & & & & \\
East Germany & 75 & 22 & 22 & 40 & - \\
1990 & 86 & 16 & 17 & 32 & 46 \\
1993 & 76 & 16 & 13 & 21 & 46 \\
1998 & & & & & \\
\hline
\end{tabular}

Database: Welfare Survey 1978, 1980, 1984, 1988, 1990-East, 1993, 1998.

The data show that the frequency of anomic reactions varies across the different dimensions. The majority of western Germans believes that they can do little to change most of our current problems. This result is, however, no cause for alarm, given that it expresses a realistic assessment in view of the few personal possibilities to bring about change in a complex society. A third of the population is inclined to be pessimistic about the future. Relatively few people complain of social isolation, alienation or disorientation. The comparison over time shows clearly that the frequency of anomic reactions has not increased, rather has remained almost stable at a relatively moderate level. The extent of alienation and pessimism has in fact decreased. The belief that there is an increasing anomic corrosion of society must be strongly doubted in the light of these empirical findings. 
The suitability of the indicators used in the Welfare Survey to measure anomic pressures was proven at the latest by the data from eastern Germany in the early 1990s. During this period of accelerated modernisation, anomic reactions appeared relatively frequently among the eastern German respondents. The large majority of the population felt helplessly at the mercy of the social upheavals and the resulting difficulties. Many suffered from disorientation: four out of ten citizens agreed that circumstances had become so complicated that they were unable to cope. The pace of catch-up modernisation has now eased, and the level of anomie has approached the value for western Germany.

Figure 1: Suicidal Mortality in West Germany and East Germany 1968-1998

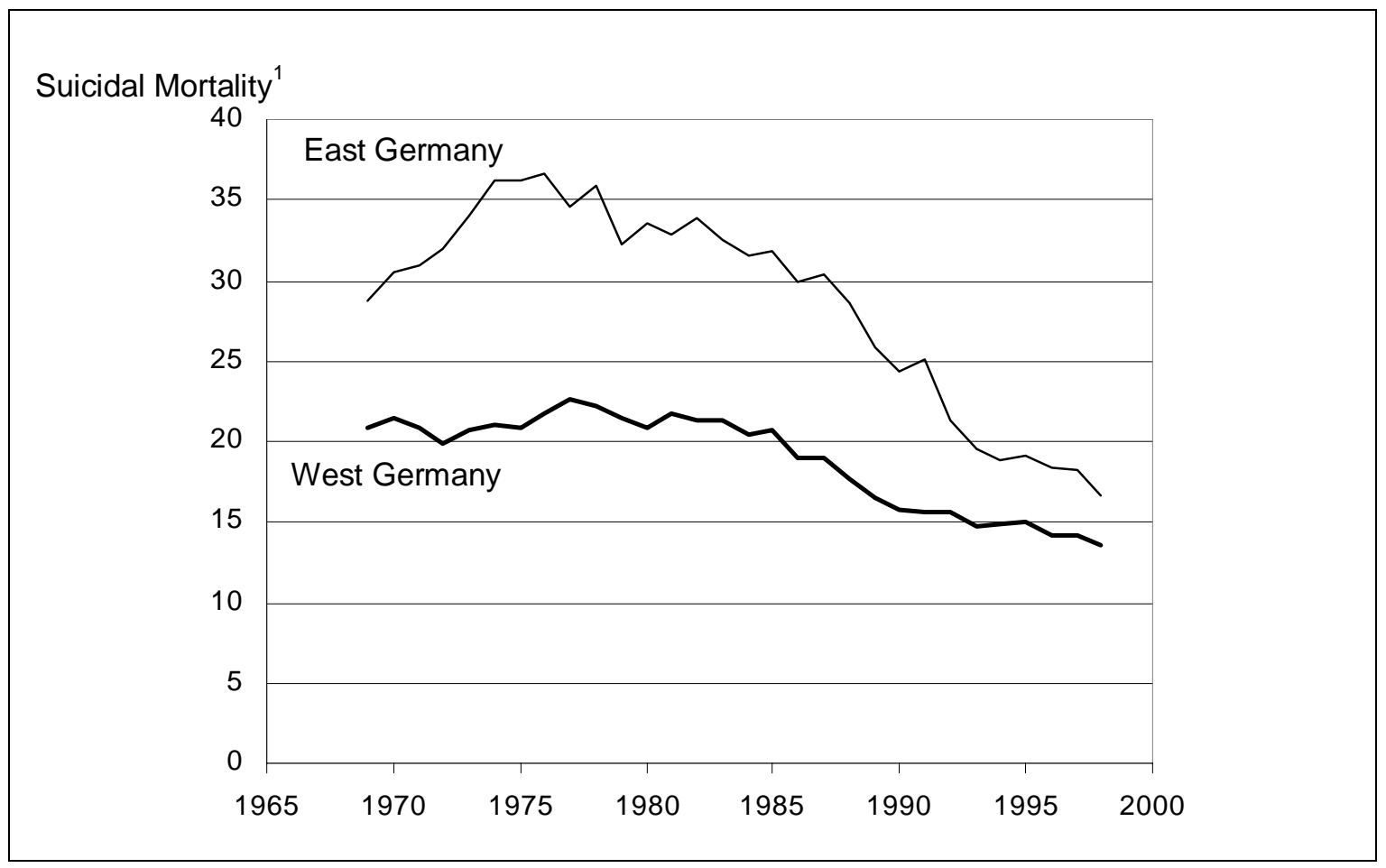

1 Standardized Mortality Rate (SMR): Number of suicides (E950-E959) per 100.000 inhabitants. Database: Bergmann et al. 1993; Official Statistics of Germany.

Suicidal mortality is a classical instrument for measuring anomie. Unlike the indicators of subjective well-being examined so far, this is an objective gauge in the broadest sense. Suicides are registered on the basis of the "International Statistical Classification of Diseases, Injuries and Causes of Death" (ICD). The ICD was introduced to both parts of Germany only in 1968, and the data on suicidality can only be compared unreservedly from that year on (Bergmann et al. 1993, p. 8).

As the data show, there was a slight increase in suicidal mortality in West Germany in the early 1970s. The economic and social upheavals described above probably contrib- 
uted to this trend, even if they were not the only factor. The trend was reversed, however, in the late 1970s, and the suicide rate declined slightly. At the end of the 1980s there was a notable decline in suicides, and in the mid-1990s a historic low of less than 15 suicides per 100,000 inhabitants was reached.

The trend was considerably more dramatic in eastern Germany, where there was a sharp rise in the suicide rate until the early 1970s. This trend can at least partly be traced back to the hermetic sealing of the country's borders and the re-intensification of state repression in the 1960s (Belau 1991; Müller 1992, pp. 1312-1314). In those years it was neither possible to demand social change nor could the people leave the country. The situation improved somewhat when the communist regime began to permit a few tens of thousands of citizens a year to leave for West Germany and when fundamental reforms were introduced in the Soviet Union in the 1980s. Both developments allowed hopes to rise, amongst some for a more liberal society and amongst others that they would be able to leave the GDR. These hopes may have contributed to the decline in suicidal mortality - possibly more so than the improvement in living conditions attained through the social policy reforms. At 29 suicides per 100,000 inhabitants, the suicide rate in 1988 was at the same level as in the late 1960s. The rate only fell below this level following the demise of the communist regime, a trend which was briefly interrupted only in 1991 .

The analyses show that there is absolutely no evidence of increased anomie in the Federal Republic of Germany - at least at the levels of attitude and action observed here. Happiness and satisfaction amongst the western German population have not decreased over the last 20 years, rather have remained stable at high levels. The level of anomie has also remained unchanged. Symptoms of stress and anxiety are observed less frequently and suicidal mortality has declined.

Despite a process of rapid modernisation in eastern Germany, the subjective well-being of the people has improved considerably: the eastern Germans are more satisfied today than in 1990, and the share of those who say they are leading a happy life has increased. Symptoms of anomie, mental strain and propensity to commit suicide have declined substantially. The example of eastern Germany has shown clearly that even highly accelerated modernisation does not perforce lead to a permanent increase in anomic reactions. 
Modernisation processes are not, therefore, inevitably accompanied by a diffusion of anomic reactions at the levels of perception and action. The thesis of the "destructive consequences of social transformation at both the individual and collective level" (Heitmeyer 1997, p. 10) must be rejected, at least for German society in general.

\section{The ambivalence of modernity}

There is general agreement that the catch-up modernisation in eastern Germany led to substantial structural fissures, to higher unemployment and increased social inequality, to a weakening of existing bonds, and to tensions between the lifeworld that had evolved and the system world that was transferred. There is no doubt that developments that can be interpreted as a "structural crisis", "regulation crisis" or "cohesion crisis" (Bohle et al. 1997, p. 59) occurred in parts of eastern German society.

Nonetheless, the eastern Germans are more satisfied and happy today than ten years ago, emerging symptoms of anomie and anxiety decreased again surprisingly quickly and suicidal mortality has declined to a remarkable extent. All these developments can be traced back primarily to the successes of the catch-up modernisation: to the enormous improvement in material living conditions, to the concession of civil and human rights, and to the liberation of the people from the dominance of the state and from enforced socialisation.

In an age of "self-propelling progress" and general "procedural melancholy" (Sloterdijk) many theorists seem to have lost sight of the positive consequences of modernisation processes. Yet theories that only see modernisation as a trigger of social crises will inevitably overlook reality. The models of anomie that are blind to social progress must be corrected, and the point of departure must be the understanding that modernisation is an ambivalent process that leads to disintegration and exclusion, but at the same time also yields new mechanisms of social integration and inclusion. In Durkheim and Weber's day, talking about the ambivalence of modernity meant demonstrating its darker sides; today we must remind ourselves of its successes. 
Figure 2: Modernisation and Subjective Well-Being

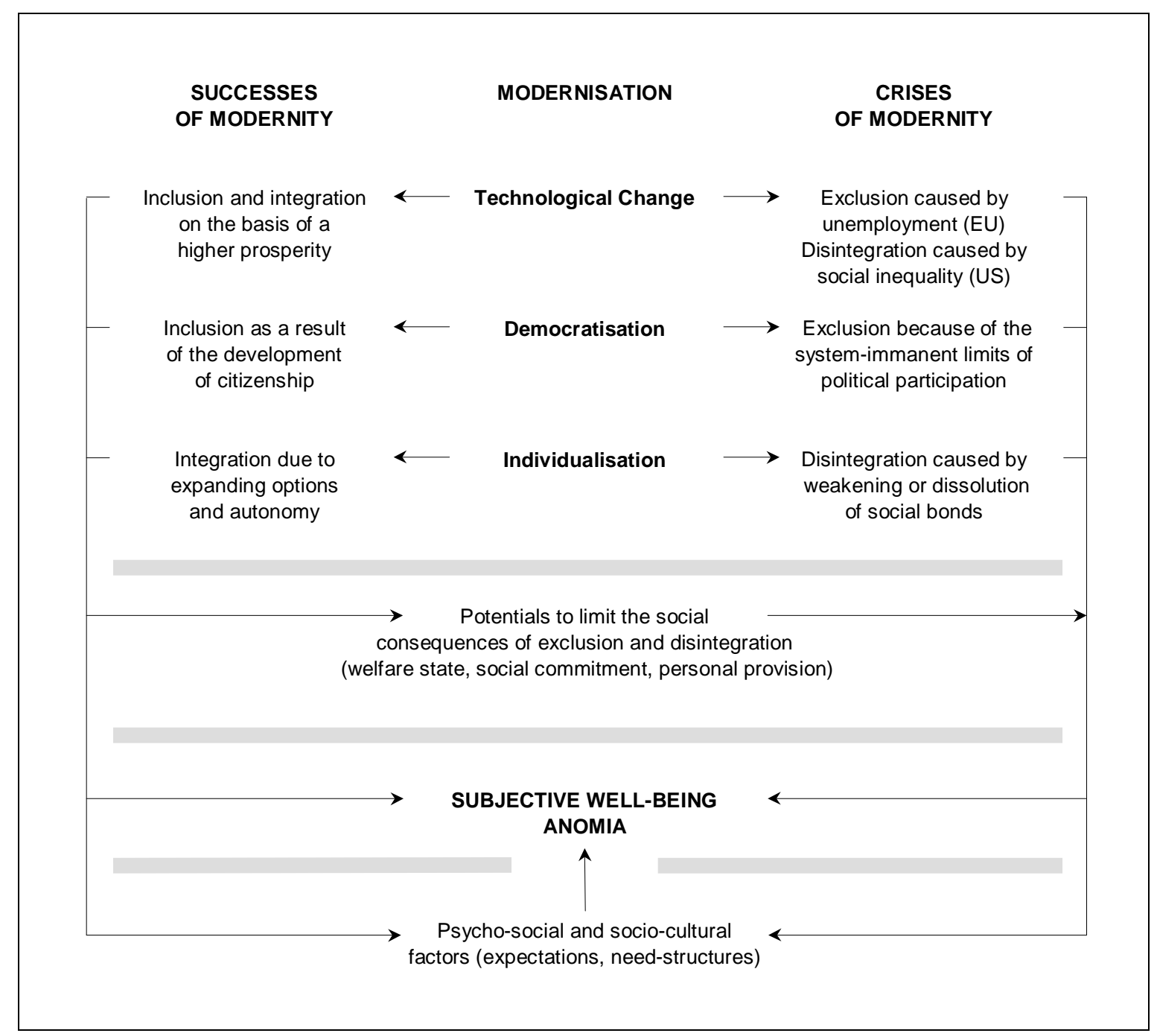

The modernisation of a national economy does not only lead to higher unemployment a problem which particularly affects the European countries (see Figure 2). And it is not only accompanied by more social inequality and increasing demands for flexibility problems which are characteristic for the United States. Technological change is also usually linked to considerable improvements in performance, which result in a higher national product. The fact that increased prosperity in the western industrialised countries has been able to yield a general improvement in living conditions can be traced back primarily to the success of another modernisation process - the development of citizenship.

Thomas H. Marshall described the development of citizenship as a process that involved the establishment of civil rights, then political rights and, finally, social rights (Marshall 1965 [1949]). Each of these rights is linked to specific achievements and institutions, 
which include equality before the law, freedom of opinion, the principle of free elections and secret ballots, and the institutionalisation of social security. When limits on personal freedom are discussed today, when the unfair distribution of wealth is lamented, or when tendencies towards weaker bonds of solidarity are pointed out, these complaints - given the existing shortcomings - are justified, indeed necessary. However, society's achievements are often disregarded in an unacceptable manner.

A third aspect of modernisation, individualisation, is also dealt with in a relatively onesided way. Usually only the disintegration of social bonds, leading to less solidarity and more social isolation, is mentioned. However, these discussions overlook the fact that the dissolution of bonds also means liberation - liberation from traditional social and cultural restraints. Individualisation also always signifies expansion of the horizon of possibilities, growing autonomy with respect to the way we plan our lives and development of a positive self-consciousness.

The ambivalence of modernity, that is, the simultaneity of successes and crises, works in a complex way on subjective well-being and the level of anomie. Firstly, it can be assumed that the positive and negative effects overlap, resulting in a partial compensation. In addition, wealth, citizenship and autonomy are themselves effective potentials to limit the social consequences of exclusion and disintegration. The modern welfare state, social commitment and personal provisions represent typical constellations of these three potentials.

The link between modernisation and well-being becomes even more complex when psycho-social and socio-cultural factors are taken into consideration: for instance, views on what constitutes a good life, ideas about an adequate standard of living and beliefs concerning the rights, freedoms and securities that should be given in a society. These ideas change - albeit relatively slowly - in the course of modernisation. To cite one example, when material living conditions improve, pretensions also increase, expectations grow and, on the basis of a secure standard of living, new ideas emerge about what is important in life and what is not. The consequences are well known: after a specific saturation point has been reached, higher incomes, greater freedom and increased consumption no longer yield satisfaction or happiness. Increasing pretensions and changing needs neutralise every further purely quantitative improvement in the standard of living. 


\section{Temporal and structural imbalances}

The effects of modernisation processes on subjective well-being and on the level of anomie essentially depend on three factors: firstly, on the degree to which new mechanisms of integration and inclusion can counterbalance disintegration and exclusion; secondly, on the existence of effective potentials that contribute to social equality and social security; and, thirdly, on the pace of social transformation.

An increase in disintegration and exclusion is the rule during periods of rapid modernisation. When, as in the case of eastern Germany, there are simultaneous gains in wealth, extended citizenship and a broadening of options and autonomy, then some of the manifestations of crisis are counterbalanced. If social security systems that cushion the trials of social upheaval also exist, then the sum effect is positive. Because levels of pretension and need structures change more slowly than living conditions, happiness and satisfaction increase and symptoms of anomie and anxiety appear ever less frequently.

If, as in most of the post-communist transition countries, the successes of modernisation do not materialise, and if there are no effective mechanisms to combat the social consequences of disintegration and exclusion, then there is an increase in anomic reactions and the levels of happiness and satisfaction decline (Seifert \& Rose 1994; Pickel \& Pickel 1996). The population can become so dissatisfied that strong feed-back effects ensue for the process of modernisation. In parliamentary elections in Poland (September 1993) and in Russia (December 1993) the post-communist parties benefited from the widespread disappointment about the economic and social costs of the transition to a market economy and won large majorities (Meyer 1997). They used their regained power first and foremost to slow down the pace of social reforms. It is still uncertain whether these feed-back effects have helped to stabilise the transformation process in the long term (Juchler 1997, p. 912) or whether the desired improvement in living conditions will fail to arrive and further frustration and instability will follow.

When, as in western Germany, modernisation proceeds at a moderate pace, then there are usually only marginal variations in subjective well-being and the level of anomie. The positive and negative consequences of modernisation overlap, and the net effect is at least partly neutralised by self-adjusting levels of pretension and changing need structures. Subjective well-being or the level of anomie are in a dynamic equilibrium 
whose stability depends particularly on individual and societal potentials to bridge crises.

However, substantial structural imbalances can be hidden behind a facade of stable well-being. In some segments of the population there are regular increases in anomic reactions, dissatisfaction and unhappiness. The reason is the simple fact that the successes and crises brought about by modernisation are distributed unequally.

Thus, for example, the consequences of individualisation can vary considerably depending on age. While younger people benefit especially from increasing autonomy and from new freedoms, the elderly are distressed by the weakening or dissolution of social bonds. The consequences of technological change are just as unequally distributed. While the majority of highly qualified employees can share in the positive effects, particularly in the form of wage increases and better working conditions, the low skilled are excluded - either through increasingly frequent unemployment, as in western Europe, or through banishment to an expanding low-wage sector, as in the USA.

More in-depth studies illustrate the extent to which these structural imbalances can lead to anomie and dissatisfaction (Glatzer \& Bös 1998). As a first example, it has already been mentioned above that suicidal mortality has declined in western Germany since the early 1980s. However, this trend does not apply equally to all age groups. Compared to the general trend, suicidality has increased amongst the elderly (Wiesner et al. 1992). As a second example, the life satisfaction of the total western German population has varied only insignificantly over the last 20 years. However, a comparison of the trends for individual income groups reveals significant differences. While the life satisfaction of higher earners has remained stable at an above-average level, the subjective well-being of low earners has frequently fluctuated around a comparatively low level.

\section{Summary}

Towards the close of the nineteenth century it was commonly asked whether individuals could live happily in modern society. After a century of many catastrophes these doubts have given way to general pessimism. The question asked today is just how unhappy modernity makes the individual. Modernisation is equated with exclusion and disintegration, while anomie, unhappiness and dissatisfaction are considered structural features 
of modern societies. However, these theses do not represent the reality. The link between modernisation and subjective well-being is more complex and dynamic than is often assumed today.

In the first place, modernity and happiness are not mutually exclusive. The widely feared increase in anomic patterns of perception and behaviour has not materialised over the last 20 years in the Federal Republic of Germany. The happiness and satisfaction of the people have remained at a high level, and the suicidal mortality rate has fallen sharply. Increased happiness and satisfaction can even ensue, as in eastern Germany, during the course of extremely rapid modernisation processes.

Secondly, modernisation is an ambivalent process. The social upheavals in eastern Germany have made it clear that modernisation not only leads to exclusion and disintegration, but that it is also accompanied - provided it is successful - by the creation of new mechanisms of inclusion and integration. Increased wealth, development of citizenship, expansion of opportunities and autonomy are some of the aspects of successful modernisation.

Thirdly, the successes and crises of modernity have complex effects on subjective wellbeing. The level and stability of subjective well-being depend substantially on the possibilities for limiting the social consequences of exclusion and disintegration. Wealth, citizenship and autonomy are essential requirements for the development of such possibilities, whatever their constellation - whether in the form of a welfare state, social commitment or personal provision.

Fourthly, structural imbalances are indications of the need to further develop the existing institutions and mechanisms of social equality. The consequences of exclusion and disintegration cannot be eliminated by the welfare state, by social commitment or by private provision; they can only be limited. Financial means cannot substitute participation in society - at best they can facilitate it. The evolution of the link between modernisation and well-being depends not least on the extent to which more effective mechanisms of social participation and integration are developed in the future. 


\section{Literature}

Beck, Ulrich, Wolfgang Bonß 1984: Soziologie und Modernisierung zur Ortsbestimmung der Verwendungsforschung, in Soziale Welt, Vol. 4, pp.381-406.

Beck, Ulrich 1996: Das Zeitalter der Nebenfolgen und die Politisierung der Moderne, in Ulrich Beck, Anthony Giddens, Scott Lash (Eds.): Reflexive Modernisierung, Eine Kontroverse, Frankfurt am Main: Suhrkamp, pp. 19-112.

Belau, Detlef 1991: Zur Interpretation suizidalen Verhaltens im Kontext sozialer und politischer Ursachen - auf dem Hintergrund sozialer Erfahrungen in der DDR, in Medizin, Mensch, Gesellschaft, Vol 4, pp. 276-284.

Benz, Wolfgang 1989: Die Bundesrepublik Deutschland 1949-1989, in Werner Weidenfeld, Hartmut Zimmermann (Eds.): Deutschland Handbuch, Eine doppelte Bilanz 1949-1989, Bonn: Bundeszentrale für politische Bildung, pp. 48-68.

Bergmann, Karl et al. (Eds.) 1993: Entwicklung der Mortalität in Deutschland von 1955-1989, Ein Datenbericht, München: MMV Medizin Verlag.

Berger, Johannes (Ed.) 1986: Die Moderne - Kontinuitäten und Zäsuren, Soziale Welt, Sonderband 4.

Bohle, Hans et al. 1997: Anomie in der Gesellschaft: Bestandsaufnahme und Kritik eines klassischen Ansatzes, in Wilhelm Heitmeyer (Ed.): Was treibt die Gesellschaft auseinander?, Frankfurt am Main: Suhrkamp, pp. 29-65.

Brie, Michael 1992: Realsozialismus zwischen antikapitalistischem Ausbruchsversuch und Selbstaufhebung, in Michael Brie, Dieter Klein (Eds.): Zwischen den Zeiten, Ein Jahrhundert verabschiedet sich, Hamburg: VSA-Verlag, pp. 57-100.

Bühl, Walter L. 1986: Strukturkrise und Strukturwandel. Zur Situation der Bundesrepublik, in Johannes Berger (Ed.) 1986: Die Moderne - Kontinuitäten und Zäsuren, Soziale Welt, Sonderband 4, pp. 141-166.

Cummins, Robert A. 1998: The second approximation to an international standard for life satisfaction, in Social Indicators Research, Vol. 43, No. 3, pp. 307-334.

Diener, Ed, C. Diener 1996: Most people are happy, in Psychological Science, Vol. 7, pp. 181185.

Diener, Ed, Eunkook Mark Suh 1999: National Differences in Subjective Well-Being, in Daniel Kahneman, Ed Diener, Norbert Schwarz (Eds.): Well-Being: The Foundations of Hedonic Psychology, New York: Russell Sage Foundation, 434-450.

Durkheim, Émile 1960 [1893]: The Division of Labor in Society, Fourth Printing, Glencoe: Free Press.

Durkheim, Émile 1963 [1897]: Suicide - A Study in Sociology, Sixth Printing, Glencoe: Free Press.

Glatzer, Wolfgang, Wolfgang Zapf (Eds.) 1984: Lebensqualität in der Bundesrepublik, Objektive Lebensbedingungen und subjektives Wohlbefinden, Frankfurt am Main, New York: Campus Verlag. 
Glatzer, Wolfgang, Mathias Bös 1998: Subjective Attendants of Unification and Transformation in Germany, in Social Indicators Research, Vol. 43, pp. 171-196.

Geißler, Rainer 1992: Die Sozialstruktur Deutschlands, Opladen: Westdeutscher Verlag.

Habermas, Jürgen 1991: Die nachholende Revolution, Frankfurt am Main: Suhrkamp.

Habich, Roland, Heinz-Herbert Noll (Eds.) 1999: Datenreport 1999 - Teil II: Lebenslagen und subjektives Wohlbefinden in Ost- und Westdeutschland, Bonn: Bundeszentrale für politische Bildung.

Heitmeyer, Wilhelm 1997: Einleitung: auf dem Weg in eine desintegrierte Gesellschaft, in Wilhelm Heitmeyer (Ed.): Was treibt die Gesellschaft auseinander?, Frankfurt am Main: Suhrkamp, pp. 9-26.

Hirschman, Albert O. 1992: Abwanderung, Widerspruch und das Schicksal der Deutschen Demokratischen Republik, in Leviathan, Vol. 3, pp. 330-358.

Juchler, Jakob 1997: Probleme der Demokratisierung in den osteuropäischen Transformationsländern, in Osteuropa, Vol. 9, pp. 898-913.

Lepsius, M. Rainer 1995: Das Legat zweier Diktaturen, in Everhard Holtmann, Heinz Sahner (Eds.): Aufhebung der Bipolarität, Veränderungen im Osten Rückwirkungen im Westen, Opladen: Leske + Budrich, pp. 23-39.

Marshall, Thomas H. 1965 [1949]: Citizenship and Social Class, in Thomas H. Marshall: Class, Citizenship and Social Development, Garden City, New York: Anchor, pp. 71-134.

Merton, Robert K. 1968: Social Theory and Social Structure, New York: The Free Press, London: Collier Macmillan Publishers.

Meyer, Gerd 1997: The Socialists' Rise to Power and the Democratization of Political Cultures in East-Central Europe, in Teresa Los-Nowak, David Armstrong (Eds.): Emerging Conceptions of Democracy in Transition Europe, Wroclaw, pp. 33-56.

Müller, Peter 1992: Suizid in der DDR - Ausfluß politischer Repression?, in Hansgünter Meyer (Ed.): Soziologie in Deutschland und die Transformation großer gesellschaftlicher Systeme, Berlin: Akademie-Verlag, pp. 1310-1316.

Pickel, Gert, Susanne Pickel 1996: Nicht nur die Politiker zählen - Einige vergleichende Ergebnisse über die Demokratisierung in Osteuropa im Zeitverlauf mit Hilfe der Central and Eastern Eurobarometer, in: ZA-Information 38, pp. 82-93.

Rose, Richard et al. 1993: Germans in Comparative Perspective, Studies in Public Policy, No. 218, Glasgow: Centre for the Study of Public Policy.

Rousseau, Jean-Jacques 1913 [1754]: The Social Contract and Discourses, Translated by G.D. Cole, London: J.M. Dent.

Seifert, Wolfgang, Richard Rose 1994: Lebensbedingungen und politische Einstellungen im Transformationsprozeß - Ostdeutschland und Osteuropa im Vergleich, discussion paper P 94-104, Wissenschaftszentrum für Sozialforschung Berlin.

Sennett, Richard 1998: The corrosion of character - The personal consequences of work in the new capitalism, New York: W. W. Norton.

Simmel, Georg 1994 [1900]: Philosophie des Geldes, in Otthein Rammstedt et al. (Eds.): Georg Simmel Gesamtausgabe, Frankfurt am Main: Suhrkamp. 
Sloterdijk, Peter 1988: Nach der Geschichte, in Wolfgang Welsch (Ed.): Wege aus der Moderne, Schlüsseltexte der Postmoderne-Diskussion, Berlin: VCH Verlagsgesellschaft, p. 262273.

Tönnies, Ferdinand 1991 [1887]: Gemeinschaft und Gesellschaft, Grundbegriffe der reinen Soziologie, Darmstadt: Wissenschaftliche Buchgesellschaft.

Veenhoven, Ruut 1992: Happiness in Nations, Subjective Appreciation of Life in 56 Nations, 1946-1992, Rotterdam: Erasmus University Rotterdam.

Weber, Hermann 1999: Geschichte der DDR, München: dtv.

Weber, Max 1958 [1946]: From Max Weber, Translated and edited by H.H. Gerth and C. Wright Mills, New York: Galaxy.

Weber, Max 1968 [1921]: Economy and Society, Translated by Günther Roth and Claus Wittich, New York: Bedminster Press.

Wiesner, G. et al. 1992: Alterssuizid in West und Ost: Trend der Suizidmortalität 1961-1989, in Bundesgesundheitsblatt, Vol. 9, pp. 442-447.

Zapf, Wolfgang 1986: Innovationschancen der westeuropäischen Gesellschaften, in Johannes Berger (Ed.): Die Moderne - Kontinuitäten und Zäsuren, Soziale Welt, Sonderband 4, pp. 167-179.

Zapf, Wolfgang 1991: Der Untergang der DDR und die soziologische Theorie der Modernisierung, in Bernd Giesen, Claus Leggewie (Eds.): Experiment Vereinigung. Ein sozialer Großversuch, Berlin: Rotbuch Verlag, pp. 38-51.

Zapf, Wolfgang 1994: Die Transformation in der ehemaligen DDR und die soziologische Theorie der Modernisierung, in Berliner Journal für Soziologie, Vol. 3, pp. 295-305. 


\section{Abteilung „Sozialstruktur und Sozialberichterstattung“ \\ - früher: Arbeitsgruppe „Sozialberichterstattung“}

Die Abteilung Sozialstruktur und Sozialberichterstattung hat einen grundlagenwissenschaftlichen Schwerpunkt in der Analyse des sozialstrukturellen Wandels moderner Gesellschaften und einen anwendungsorientierten Schwerpunkt in der Sozialberichterstattung; die Forschungsaufgaben liegen in der Dauerbeobachtung des sozialstrukturellen Wandels und der Wohlfahrtsentwicklung. Die theoretischen Orientierungen stammen aus der Modernisierungstheorie und der Theorie der Wohlfahrtsproduktion.

MitarbeiterInnen in der Abteilung „Sozialstruktur und Sozialberichterstattung“

Prof. Dr. Wolfgang Zapf (Leiter)

Dr. Roland Habich (Koordinator)

Petra Böhnke, Diplomsoziologin Thomas Bulmahn, Diplomsoziologe Jan Delhey, Diplomsoziologe Dr. Katrin Gillwald

Dr. Wilhelm Hinrichs Dr. sc. Eckhard Priller

Annett Schultz, Diplomsoziologin
Bitte senden Sie mir die folgenden Veröffentlichungen zu

Pro paper bitte 1 DM-Briefmarke beilegen

- Bitte einen beschrifteten Adressenaufkleber beilegen •

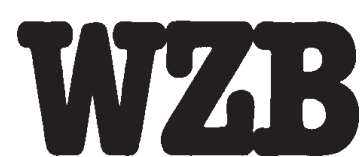

WISSENSCHAFTZENTRUM BERLIN FÜR SOZIALFORSCHUNG

\section{Paper-Nr., Autor}

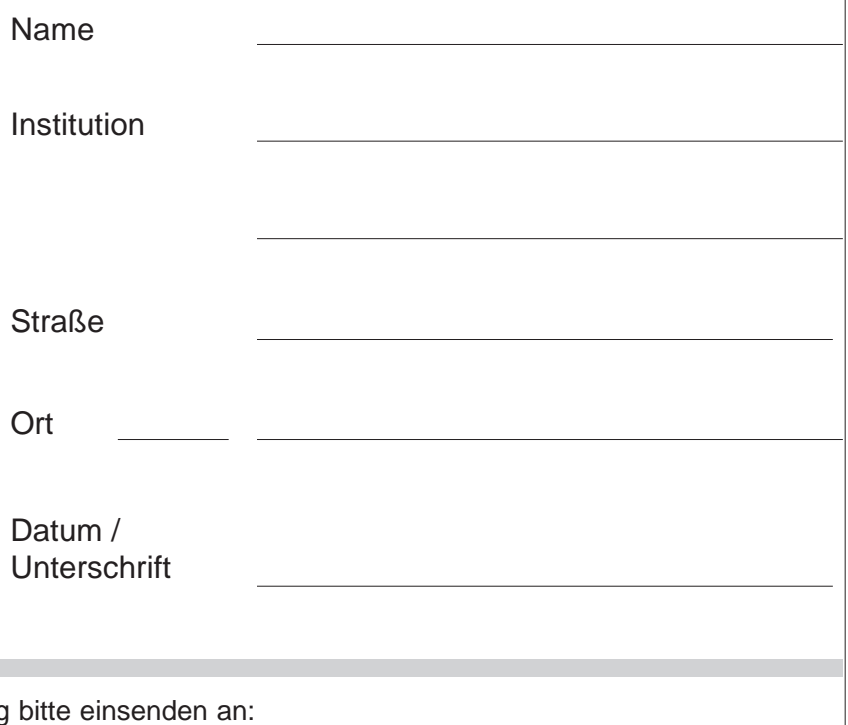

Bestellung bitte einsenden an 

Forschungsschwerpunkt III "Sozialer Wandel, Institutionen und Vermittlungsprozesse"

Auswahl der Arbeitspapiere (Stand: März 2000)

\author{
Abteilungsübergreifend \\ FS III 96-301 The Mass Media and Modern Government \\ Kenneth Newton \\ FS III 96-302 Das intermediäre System der Politik als Orientierungssystem der Bürger \\ Dieter Fuchs, Edeltraud Roller, Dieter Rucht und Bernhard Weßels
}

\title{
Abteilung 1 "Öffentlichkeit und soziale Bewegungen"
}

FS III 90-101 Strukturen und Funktionen moderner Öffentlichkeit. Fragestellungen und Ansätze. Jürgen Gerhards und Friedhelm Neidhardt

FS III 92-101 Anbieter von öffentlichen politischen Veranstaltungen in West-Berlin.

Barbara Blattert

Nachfrager und wahrgenommenes Angebot von öffentlichen politischen Veranstaltungen in der Bundesrepublik.

Jürgen Gerhards

FS III 92-103 Dokumentation und Analyse von Protestereignisssen in der Bundesrepublik Deutschland (Prodat), Codebuch.

Dieter Rucht, Peter Hocke und Thomas Ohlemacher

FS III 93-101 Westeuropäische Integration und die Schwierigkeiten der Entstehung einer europäischen Öffentlichkeit.

Jürgen Gerhards

FS III 93-102 Selbstkontrolle in den Medien: Der Deutsche Presserat und seine Möglichkeiten.

Jessica Eisermann

FS III 93-103 Prominenz in der Bundesrepublik.

Birgit Peters

FS III 94-101 Von den Oppositionsgruppen der DDR zu den neuen sozialen Bewegungen in Ostdeutschland?

Barbara Blattert, Dieter Rink und Dieter Rucht

FS III 95-101 A Burning Question: Explaining the Rise of Racist and Extreme Right Violence in Western Europe.

Ruud Koopmans

FS III 95-103 German Unification, Democratization and the Role of Social Movements: A Missed Opportunity.

Dieter Rucht

FS III 95-105 Diskursanalyse im Zeit- und Ländervergleich. Methodenbericht über eine systematische Inhaltsanalyse zur Erfassung des öffentlichen Diskurses über Abtreibung in den USA und der Bundesrepublik in der Zeit von 1970 bis 1994.

Jürgen Gerhards und Monika Lindgens

FS III 97-101 Citizenship, National Identity and the Mobilisation of the Extreme Right. A Comparison of France, Germany, the Netherlands and Switzerland

Ruud Koopmans and Hanspeter Kriesi 
FS III 98-101 Proteststrukturen im Ost-West-Vergleich 1989 - 1992

Susann Burchardt

FS III 98-103 Die Branchenstruktur der Markt- und Meinungsforschung in der Bundesrepublik Deutschland von 1986 bis 1996. Eine deskriptive Analyse Simone Wack

FS III 98-104 Konjunkturen der NS-Bewegung. Eine Untersuchung der Veranstaltungsaktivitäten der Münchener NSDAP, 1925-1930

Helmut K. Anheier, Friedhelm Neidhardt und Wolfgang Vortkamp

FS III 98-105 Challenging the Liberal Nation-State? Postnationalism, Multiculturalism, and the Collective Claims-Making of Migrants and Ethnic Minorities in Britain and Germany Ruud Koopmans and Paul Statham

FS III 98-106 Die Stimme der Medien im politischen Prozeß - Themen und Meinungen in Pressekommentaren Friedhelm Neidhardt, Christiane Eilders und Barbara Pfetsch

FS III 98-107 Methodenbericht zum Projekt: Die Stimme der Medien im politischen Prozeß - Themen und Meinungen in Pressekommentaren

Christiane Eilders und Albrecht Lüter

FS III 99-101 Government News Management - Strategic Communication in Comparative Perspective Barbara Pfetsch

FS III 99-102 (Re)constructing Community in Berlin; Of Jews, Turks and German Responsibility Jonathan Laurence

FS III 99-103 "In Russia we were Germans, and now we are Russians." - Dilemmas of Identity Formation and Communication among German-Russian Aussiedler Barbara Pfetsch

\section{Abteilung 2 "Institutionen und sozialer Wandel"}

FS III 91-201 Ein analytisches Schema zur Klassifikation von Politikinhalten. Edeltraud Roller

FS III 93-202 Eine Metatheorie des demokratischen Prozesses. Dieter Fuchs

FS III 93-203 A Metatheory of the Democratic Process. Dieter Fuchs

FS III 93-205 Mass Media: Political Independence of Press and Broadcasting Systems. Katrin Voltmer

FS III 94-201 Democratic Transformation and the Prerequisites of Democratic Opposition in East and Central Europe.

Bernhard Wessels und Hans-Dieter Klingemann

FS III 94-202 Cultural Conditions of the Transformation to Liberal Democracies in Central and Eastern Europe.

Dieter Fuchs und Edeltraud Roller

FS III 94-206 The Evolution of Western Foreign Aid Programs.

Thomas R. Cusack und Joyce P. Kaufman

FS III 96-201 Political Science: The Discipline.

Robert E. Goodin und Hans-Dieter Klingemann 
FS III 96-202 Contexts of Political Protest in Western Democracies: Political Organization and Modernity.

Edeltraud Roller und Bernhard Wessels

FS III 96-203 Problemreich und konfliktgeladen: Lokale Demokratie in Deutschland fünf Jahre nach der Vereinigung.

Thomas R. Cusack und Bernhard Weßels

FS III 96-204 Social Alliances and Coalitions: The Organizational Underpinnings of Democracy in West Germany.

Bernhard Wessels

FS III 96-205 Abbau des Sozialstaats. Einstellungen der Bundesbürger zu Kürzungen von Sozialleistungen in den neunziger Jahren.

Edeltraud Roller

FS III 96-206 System Characteristics Matter: Empirical Evidence from Ten Representation Studies. Bernhard Wessels

FS III 96-207 Wohin geht der Wandel der demokratischen Institutionen in Deutschland? Die Entwicklung der Demokratievorstellungen der Deutschen seit ihrer Vereinigung.

Dieter Fuchs

FS III 96-208 Legislative Recruitment in Germany: Professionalization or Political Class?

Bernhard Wessels

FS III 97-201 Social Capital, Institutional Structures, and Democratic Performance: A Comparative Study of German Local Governments.

Thomas R. Cusack

FS III 97-202 The Electoral Process in the Unified Germany.

Dieter Fuchs und Robert Rohrschneider

FS III 97-203 Kriterien demokratischer Performanz in Liberalen Demokratien Dieter Fuchs

FS III 98-201 Vom Konsens zum Dissens? Politische Ordnungspräferenzen von Eliten und Bürgern im ost-westdeutschen Vergleich.

Christian Welzel

FS III 98-202 Mapping Political Support in the 1990s: A Global Analysis.

Hans-Dieter Klingemann

FS III 98-203 Remembering the Bad Old Days: Human Rights, Economic Conditions, and Democratic Performance in Transitional Regimes.

Hans-Dieter Klingemann and Richard I. Hofferbert

FS III 98-204 The Political Culture of Unified Germany

Dieter Fuchs

FS III 99-201 Näherung oder Richtung? Der Theorienstreit der Wahlforschung aus der Sicht politischer Repräsentation.

Christian Welzel und Thomas R. Cusack

FS III 99-202 Analyzing Democratic Change and Stability: A Human Development Theory of Democracy.

Christian Welzel and Ronald Inglehart

FS III 99-203 Soziale Integration und politische Institutionen in modernen Gesellschaften.

Dieter Fuchs 
FS III 99-204 Die demokratische Gemeinschaft in den USA und in Deutschland.

Dieter Fuchs

FS III 99-205 Political Consequences of Germany's Mixed-Member System: Personalization at the Grass-Roots?

Hans-Dieter Klingemann and Bernhard Wessels

FS III 00-201 Structures of diversity of press and broadcasting systems: The institutional context of public communication in Western democracies

Katrin Voltmer

\section{Abteilung 3 "Sozialstruktur und Sozialberichterstattung"}

FS III 95-401 Wie Migranten leben. Lebensbedingungen und soziale Lage der ausländischen Bevölkerung in der Bundesrepublik.

hrsg. von Wolfgang Seifert

FS III 95-402 Familie und Erwerbsarbeit in der Bundesrepublik. Rückblick, Stand der Forschung und Design einer Lebensformentypologie.

Karin Schulze Buschoff

FS III 95-403 Erwerbsverläufe in Ostdeutschland. Einflüsse und Folgen.

Horst Berger, Thomas Bulmahn und Wilhelm Hinrichs

FS III 95-404 Sozialberichterstattung in und für Deutschland - ein Ziel, zwei Wege? Dokumentation einer Arbeitstagung zu "Sozialreport 1994" - "Datenreport 1994".

hrsg. von Roland Habich, Wolfgang Zapf und Gunnar Winkler

FS III 95-406 Developments in Satisfaction Research.

Ruut Veenhoven

FS III 95-408 Ökologisierung von Lebensstilen. Argumente, Beispiele, Einflußgrößen.

Katrin Gillwald

FS III 96-401 Mobilität zur sozialen Teilhabe Älterer.

Heidrun Mollenkopf und Pia Flaschenträger

FS III 96-402 Lebenszufriedenheit im europäischen Vergleich.

Ingeborg Weller

FS III 96-403 Vereinigungsbilanzen. Die deutsche Einheit im Spiegel der Sozialwissenschaften. Thomas Bulmahn

FS III 96-404 Happy Life-Expectancy. A comprehensive measure of quality-of-life in nations. Ruut Veenhoven

FS III 96-405 Response Style und Response Set. Eine Längsschnittuntersuchung zu den Zufriedenheitsund Einstellungsfragen im Sozio-ökonomischen Panel.

Jörg-Peter Schräpler

FS III 96-406 Rethinking Modernization: Legacies of Parsons and Hilbert. Edward A. Tiryakian

FS III 96-407 Wohnortwechsel zwischen den Bundesländern im Kontext der Vereinigung. Wilhelm Hinrichs

FS III 97 - 401 Ungleichheits- und Gerechtigkeitsorientierungen in modernen Wohlfahrtsstaaten. Ein Vergleich der Länder Schweden, Großbritannien und der Bundesrepublik Deutschland Steffen Mau 
FS III 97 - 402 Die Sozialstruktur der DDR. Versuch einer Rekonstruktion auf der Basis einer 1987 dur4chgeführten soziologischen Untersuchung

Siegfried Grundmann

FS III 97 - 403 Lebensstile und Wohnverhältnisse Annette Spellerberg

FS III 97 - 404 Wohnmobilität und Wohnverhältnisse in West- und Ostdeutschland Nicole Schneider

FS III 97 - 405 Privathaushalte und Haushalten in Ostdeutschland Annett Schultz

FS III 97 - 406 Ein Fall von Car Sharing: Umweltentlastung durch soziale Innovation Katrin Gillwald

FS III 97 - 407 Soziologische Forschung in der DDR. Einige Aspekte der Arbeit des Wissenschaftlichen Rates Rudi Weidig

FS III 97 - 408 Sozialindikatorenforschung in der DDR. Wissenschaftstheoretische, forschungsorganisatorische und institutionelle Aspekte Horst Berger

FS III 97 - 409 Wohnbedingungen und ihre subjektive Wahrnehmung in Ostdeutschland 1990-97 Wilhelm Hinrichs

FS III 97 - 410 Arbeitszeiten - Wunsch und Wirklichkeit in Ost- und Westdeutschland Karin Schulze Buschoff

FS III 97 - 411 Ein Suchen und Sichfinden im Gestern und Heute. Verändern die Ostdeutschen ihre Einstellungen und Haltungen zur Demokratie und gesellschaftlichen Mitwirkung? Eckhard Priller

FS III 98 - 401 Inequality and Support for Redistributive Policy: One World of Post-Communism, Two Worlds of Western Capitalism?

Jan Delhey

FS III 98 - 402 Über die Möglichkeit einer kontinuierlichen und zügigen Fortsetzung des chinesischen Modernisierungsprozesses

Li Pengcheng

FS III 98 - 403 Lebensstile im Zeitvergleich: Typologien für West- und Ostdeutschland 1993 und 1996 Annette Spellerberg und Regina Berger Schmitt

FS III 98 - 404 Teilzeitbeschäftigte in Europa. Arbeitsbedingungen, Familienkontext, Motive und subjektive Bewertungen

Karin Schulze Buschoff und Jana Rückert

FS III 98 - 405 Das Erwerbsverhalten von Frauen im europäischen Vergleich. Welche Faktoren beeinflussen Arbeitszeiten und Arbeitszeitwünsche? Karin Schulze Buschoff, Inge Weller und Jana Rückert

FS III 98 - 406 Rette sich, wer kann? Die Krise der gesetzlichen Rentenversicherung und die Privatisierung der Altersvorsorge

Thomas Bulmahn

FS III 98 - 407 Taking Stock: German Unification as Reflected in the Social Sciences Thomas Bulmahn

FS III 99 - 401 Wohnsuburbanisierung am Beispiel Berlin. Ein Erklärungsrahmen Wilhelm Hinrichs 
FS III 99 - 402 Income Dynamics in Three Societies. An investigation of social dynamics using "old" and "new" types of social indicators

Zsolt Spéder, Roland Habich

FS III 99 - 403 Inequality and Attitudes. Postcommunism, Western Capitalism and Beyond Jan Delhey

FS III 99 - 404 Social Reporting in the 1970s and 1990s

Wolfgang Zapf

FS III 99 - 405 New Structures of Inequality. Some Trends of Social Change in Modernized Societies Heinz-Herbert Noll

FS III 99 - 406 Teilzeitarbeit in Schweden, Großbritannien und Deutschland. Individuelle Dynamik und Haushaltskontext im Ländervergleich

Karin Schulze Buschoff unter Mitarbeit von Jana Rückert-John

FS III 99 - 407 Komparative und nicht-komperative Ansätze zur Analyse der Europäisierung der Sozialstrukturen Bernhard Schäfers

FS III 99 - 408 Lebensstandard und Armut im vereinten Deutschland Petra Böhnke, Jan Delhey

FS III 99 - 409 Entwicklung der Wohnverhältnisse in Ost- und Westdeutschland Wilhelm Hinrichs

FS III 99 - 410 Demokratieentwicklung und Mitwirkung in Ostdeutschland Eckhard Priller

FS III 99 - 411 Attribute einer lebenswerten Gesellschaft: Freiheit, Wohlstand, Sicherheit und Gerechtigkeit Thomas Bulmahn

FS III 99 - 412 Über die materielle zur inneren Einheit? Wohlstandslagen und subjektives Wohlbefinden in Ost- und Westdeutschland Jan Delhey, Petra Böhnke

FS III 99 - 413 Poverty in a Multidimensional Perspective. Great Britain and Germany in Comparison Petra Böhnke, Jan Delhey 
Die Arbeitspapiere können bestellt werden/The discussion papers can be ordered:

Wissenschaftszentrum Berlin für

Sozialforschung (WZB)

Pressestelle

Reichpietschufer 50

D-10785 Berlin

Bestellungen von Arbeitspapieren: Briefmarken erbeten

Wir erbitten von allen Bestellern, die Arbeitspapiere vom WZB anfordern, eine 1 DM-Briefmarke pro Papier als pauschalen Beitrag zu den anfallenden Versandkosten. Besteller aus dem Ausland werden gebeten, für jedes bestellte Arbeitspapier einen "Coupon-Réponse International" (internationalen Antwortschein), der auf Postämtern erhältlich ist, beizufügen.

Aus diesem Grund ist es auch nicht mehr möglich, Bestellungen von Arbeitspapier per Telefon oder Fax an das WZB zu richten. Schicken Sie Ihre Bestellungen nur noch schriftlich an die WZB-Pressestelle, und legen Sie neben der entsprechenden Anzahl von Briefmarken weiterhin einen mit Ihrer eigenen Adresse versehenen Aufkleber bei.

Die in letzter Zeit erheblich gestiegene Anzahl von Bestellungen sowie die Mittelkürzungen, die öffentlich finanzierten Institutionen - wie auch dem WZB auferlegt wurden, machen diese Maßnahme unumgänglich. Wir bitten um Verständnis und darum, unbedingt wie beschrieben zu verfahren.

Stamps for Papers

We ask for a 1 DM-postage stamp per paper from all those who wish to order WZBpapers and who live in Germany. These stamps contribute to the shipment costs incurred. All persons interested in WZB-papers from abroad are kindly requested to send one "Coupon-Réponse International" (international reply coupon) for each ordered paper. The coupons can be obtained at your local post office.

The reasons for these measures are the high increase in the number of ordered papers during the last months as well as the cut in funds imposed on publicly financed institutions like the WZB. We do ask for your understanding and hope that you will comply with the above mentioned procedure. 
